\title{
THE BRANCH EXPANSION AND THE PERFORMANCE OF THE BANKS: THE CASE OF INDONESIA
}

\author{
Hery Prasetyo ${ }^{7}$ \\ Sony Sunaryo ${ }^{2}$
}

\begin{abstract}
Opening new branches may help the banks to expand and is a priority for the banks to enlarge the public inclusion. Indonesian banking industry is currently not efficient and still focus more on networking the branches than improving the banking access to the public. This paper utilize the path analysis to see the link betweeen the branch expansion and the performance of the banks. The analysis shows that the increase of the number of branches and employees does not significantly influence the financial performance of the banking industry from the period of 2011-2012. This prove that the inefficiency of banking industry as one of the performance indicators of banking is not the main factor that be caused by increasing the number of branches and employees.
\end{abstract}

Keywords: Number of branches and employees, Financial performance of industrial banking, Path Analysis.

JEL Classification: G21, L11

1 Postgraduate at Magister Manajemen Teknologi, Institut Teknologi Sepuluh Nopember; jangur35@gmail.com

2 Lecturer at Magister Manajemen Teknologi, Institut Teknologi Sepuluh Nopember; sonny s@statistika.its.ac.id 


\section{PENDAHULUAN}

Besarnya pangsa pasar yang belum tergarap membuat perbankan di tanah air memiliki kesempatan untuk berekspansi seluas-luasnya. Hal ini sejalan dengan program pemerintah yang menginginkan perluasan pelayanan perbankan di seluruh Indonesia. Salah satu yang dilakukan perbankan di Indonesia adalah dengan membuka cabang sebanyak-banyaknya agar dapat lebih dekat dengan nasabah dan memperluas pelayanan perbankan di seluruh Indonesia. Pembukaan cabang masih menjadi prioritas utama perbankan untuk inklusif kepada masyarakat.

Industri perbankan mempunyai peranan yang amat penting terhadap pembangunan ekonomi. Sejarah perekonomian Indonesia menunjukkan bahwa ekonomi bangsa ini bergerak seiring dengan industri perbankan. Ekonomi Indonesia adalah bank-based economy, sebuah perekonomian yang bergantung pada keberadaan perbankan sebagai sumber pembiayaan. Oleh sebab itu, upaya memperkuat sistem perbankan yang sehat, efisien dan bermanfaat bagi perekonomian menjadi kunci keberhasilan dalam menjaga keberlangsungan pembangunan ekonomi nasional.

Krisis ekonomi tahun 1997 merupakan pelajaran yang sangat berharga bagi regulator perbankan Indonesia tentang pentingnya prinsip kehati-hatian (prudential regulation) dalam mengelola sistem perbankan. Setelah krisis ekonomi tahun 1997 - 1998, industri perbankan mengalami perubahan drastis dalam jumlah bank. Jika pada tahun 1998 jumlah bank umum mencapai 208, maka pada tahun 2006 jumlah bank umum turun menjadi 130 bank dan terus menurun hingga pada Desember tahun 2009, jumlah bank umum menjadi 121 bank seperti tampak pada Tabel 1. Penurunan jumlah bank disebabkan adanya pencabutan ijin usaha dan merger bank. Proses konsolidasi melalui upaya memperkuat permodalan dan merger disinyalir akan terus terjadi di masa depan seiring dengan program Arsitektur Perbankan Indonesia yang diluncurkan pada 9 Januari 2004. Arsitektur Perbankan Indonesia (API) merupakan suatu kerangka dasar sistem perbankan Indonesia yang bersifat menyeluruh dan memberikan arah, bentuk, dan tatanan industri perbankan untuk rentang waktu lima sampai sepuluh tahun. Arah kebijakan pengembangan industri perbankan di masa datang yang dirumuskan dalam API dilandasi oleh visi mencapai suatu sistem perbankan yang sehat, kuat dan efisien guna menciptakan kestabilan sistem keuangan dalam rangka membantu mendorong pertumbuhan ekonomi nasional.

\begin{tabular}{|c|c|c|c|c|c|c|c|c|c|}
\hline \multicolumn{10}{|c|}{$\begin{array}{c}\text { Tabel 1 } \\
\text { Perkembangan Jumlah Bank (1998-2009) }\end{array}$} \\
\hline Jumlah & 1998 & 2000 & 2002 & 2004 & 2005 & 2006 & 2007 & 2008 & 2009 \\
\hline Bank Umum*) & 208 & 151 & 141 & 133 & 131 & 130 & 130 & 124 & 121 \\
\hline Kantor & 7661 & 7113 & 7001 & 7839 & 8236 & 9110 & 9680 & 10868 & 12837 \\
\hline
\end{tabular}


Pada tahun 2008 setelah terjadinya krisis global di sektor finansial, walaupun Bank Indonesia telah memangkas BI rate sebagai tingkat bunga acuan perbankan, namun industri perbankan Indonesia belum mau merespon kebijakan ini dengan cepat. Artinya, perbankan sebagai lembaga intermediasi masih enggan menyalurkan kreditnya dengan suku bunga kredit yang rendah yang pada akhirnya sektor riil tidak dapat menjalankan peranannya dalam perekonomian karena terhambat faktor pembiayaan. Ketika perbankan Indonesia berada dalam struktur pasar yang tidak kompetitif (imperfect competition), maka bank-bank umum nasional tidak akan terpacu untuk meningkatkan efisiensi. Salah satu inefisiensi di industri perbankan tercermin dari tingginya rasio perbandingan antara biaya operasional dengan pendapatan operasional (BOPO). Menurut data yang tersaji pada Tabel 2 bahwa BOPO rata-rata perbankan masih di atas 80 persen, padahal efisiensi perbankan merupakan sarana penting efektivitas kebijakan moneter mengingat industri perbankan sebagai transmisi kebijakan moneter kepada sektor riil. Di sisi lain, sektor perbankan mempertahankan marjin yang besar untuk memperoleh profit atau laba supernormal terlihat dari data yang tersaji di Tabel 2 yang menunjukkan nilai Net Interest Margin (NIM) yang masih tinggi yaitu jauh di atas 5 persen bahkan tertinggi dibandingkan NIM Negara lain di kawasan ASIA, padahal nilai NIM yang ideal berkisar antara 3-5 persen menurut Pjs. Gubernur Bank Indonesia Darmin Nasution. Hal ini menunjukkan bahwa perbankan Indonesia sebagai entitas bisnis berusaha mempertahankan tingginya spread suku bunga kredit dengan suku bunga simpanan sebagai strategi perilaku maksimisasi laba. Permasalahan utama yang menjadi kunci penting untuk dilakukan penelitian ini adalah industri perbankan Indonesia dinilai belum efisien, karena masih fokus membangun jaringan kantor cabang dibandingkan meningkatkan akses perbankan kepada masyarakat. Inefisiensi tersebut menjadi persoalan yang dihadapi perbankan menjelang implementasi Masyarakat Ekonomi Asean (MEA) tahun 2015, MEA keuangan tahun 2020.

\begin{tabular}{l|r|r|r|r|r|r|r}
\multicolumn{7}{c}{ Tabel $\mathbf{2}$} \\
\multicolumn{1}{c|}{ Indikator Kinerja Bank Umum (2003-2009) } \\
INDIKATOR UTAMA & $\mathbf{2 0 0 3}$ & $\mathbf{2 0 0 4}$ & $\mathbf{2 0 0 5}$ & $\mathbf{2 0 0 6}$ & $\mathbf{2 0 0 7}$ & $\mathbf{2 0 0 8}$ & \multicolumn{2}{c}{$\mathbf{2 0 0 9}$} \\
ASET (Trilyun Rp) & 1.213 & 1.272 & 1.469 & 1.693 & 1.986 & 2.310 & 2.534 \\
\hline DPK (Trilyun Rp) & 888 & 963 & 1.127 & 1.287 & 1.510 & 1.753 & 1.973 \\
\hline KREDIT (Trilyun Rp) & 440 & 559 & 695 & 792 & 1.002 & 1.307 & 1.437 \\
\hline NPL (\%) & 6,78 & 4,50 & 7,56 & 6,07 & 4,07 & 3,82 & 3,31 \\
\hline CAR (\%) & 19,43 & 19,42 & 19,30 & 21,27 & 19,30 & 16,76 & 17,42 \\
\hline ROA (\%) & 2,63 & 3,46 & 2,56 & 2,64 & 2,78 & 2,33 & 2,60 \\
\hline BOPO (\%) & 88,10 & 76,64 & 89,50 & 86,98 & 84,05 & 88,59 & 86,63 \\
\hline NIM (\%) & 4,64 & 5,88 & 5,63 & 5,80 & 5,70 & 5,66 & 5,56 \\
\hline LDR (\%) & 43,52 & 49,95 & 59,66 & 61,56 & 66,32 & 74,58 & 72,88 \\
\hline
\end{tabular}

Sumber : Statistik Perbankan Indonesia berbagai tahun, Bank Indonesia (diolah) 
Berdasarkan data Bl, untuk melayani 250 juta penduduk Indonesia, bank lebih banyak fokus membangun kantor cabang. Dari 18 ribu kantor dan 7.000 mesin anjungan tunai mandiri (ATM), ditambah adanya 4.000 kantor bank perkreditan rakyat (BPR), perbankan Indonesia hanya mampu mengakses 20\% masyarakat produktif, atau baru 30 juta jiwa. Padahal, jika dibandingkan dengan negara tetangga, misalnya Malaysia atau Thailand, Indonesia masih tertinggal. Pokok persoalannya adalah investasi pembukaan kantor yang lebih tinggi daripada peningkatan akses teknologi informasi. Thailand yang hanya memiliki 33 bank dan 56 ribu cabang dapat menjangkau 73\% masyarakat produktif. Begitu juga di Malaysia dengan 15 ribu kantor cabang, jangkauan perbankan di negara tersebut mencakup 66\% masyarakat usia produktif.

Yang menarik dari perbankan di Indonesia adalah meskipun BOPO masih belum efisien dan masih gencar sekali membuka cabang atau jaringan dan menambah jumlah pegawai, namun laba yang berhasil diraih perbankan Indonesia dinilai menjadi yang tertinggi dibanding negara-negara ASEAN lainnya.

Untuk itulah diperlukan analisa terhadap kaitan ekspansi jumlah cabang dan jumlah pegawai terhadap kinerja perbankan di Indonesia agar dapat digambarkan hubungan yang terjadi antara penambahan jumlah cabang dan jumlah pegawai terhadap efisiensi perbankan (BOPO), penyaluran kredit (/oan to deposit ratio/LDR), pembiayaan bermasalah (non performance loan/NPL), besarnya net interest margin (NIM) terhadap rentabilitas (return on asset/ROA) dan (return on equity/ROE) industri perbankan di Indonesia menggunakan Path Analysis sebagai tujuan dari penelitian ini.

Dari hasil analisa tersebut diharapkan dapat menjawab apakah pengaruh pembukaan cabang dan penambahan pegawai terhadap kinerja industri perbankan, sekaligus juga menjawab apakah penyebab utama inefisiensi industri perbankan di Indonesia adalah karena industri perbankan di Indonesia masih fokus membangun jaringan kantor cabang sekaligus penambahan pegawai, mengingat hal tersebut menjadi persoalan yang dihadapi industri perbankan menjelang implementasi Masyarakat Ekonomi Asean (MEA) tahun 2015 dan MEA keuangan tahun 2020.

\section{TEORI}

Paper ini menganalisa peran strategi pembukaan cabang terhadap kinerja perbankan; diukur dengan beberapa indikator kinerja terukur meliputi profitabilitas, rentabilitas, likuiditas, pengelolaan resiko, dan kemampuan pengelolaan aktiva produktif. Bagian pertama dari bab ini menguraikan indikator kinerja perbankan yang akan digunakan tersebut. Selanjutnya pengembangan model teoritis dilakukan untuk mencari hubungan berdasar antara pengaruh pembukaan cabang terhadap kinerja perbankan. 


\subsection{Kinerja Perbankan}

Variabel return on asset (ROA) mewakili profitabilitas perbankan, sebagaimana return on equity (ROE) dan return on capital (ROC). ROA dianggap sebagai variabel yang paling tepat dalam menggambarkan profitabilitas industri perbankan (Berger, 2009). Penghitungan Rasio ROA adalah sama dengan Laba Sebelum Pajak dalam 12 bulan terakhir / Rata-rata Aktiva dalam periode yang sama (sesuai SE BI No.30/2/UPPB tgl 30 April 1997) dengan satuan persen (\%).

Ukuran kinerja perbankan kedua adalah rasio rentabilitas (earnings). Keberhasilan bank didasarkan pada penilaian kuantitatif terhadap rentabilitas bank dapat diukur dengan menggunakan rasio biaya operasional terhadap pendapatan operasional atau BOPO (Kuncoro dan Suhardjono, 2002). Bank Indonesia menetapkan angka terbaik untuk rasio BOPO adalah di bawah 90\%, karena jika rasio BOPO melebihi 90\% hingga mendekati angka 100\% maka bank tersebut dapat dikategorikan tidak efisien dalam menjalankan operasionalnya. Pada tahun 2013 BI menerbitkan aturan rasio BOPO berdasarkan bank umum kelompok usaha (BUKU). Maksimal BOPO BUKU I maksimal 85\%, BUKU II kisaran 78\% - 80\%, BUKU III 70-75\% dan BUKU IV 65\%-60\%. Menurut Dendawijaya (2003) rasio biaya operasional digunakan untuk mengukur tingkat efisiensi dan kemampuan bank dalam melakukan kegiatan operasionalnya. Rasio Biaya Operasional terhadap Pendapatan Operasional (BOPO) sering disebut rasio efisiensi digunakan untuk mengukur kemampuan manajemen bank dalam mengendalikan biaya operasional terhadap pendapatan operasional. Semakin kecil rasio ini berarti semakin efisien biaya operasional yang dikeluarkan bank bersangkutan (Almilia dan Herdiningtyas, 2005).

BOPO dihitung dari rasio antara biaya operasional terhadap pendapatan operasional (SE BI No 6/73/INTERN DPNP tgl 24 Desember 2004). Biaya operasional dihitung berdasarkan penjumlahan dari total beban bunga dan total beban operasional lainnya. Pendapatan operasional adalah penjumlahan dari total pendapatan bunga dan total pendapatan operasional lainnya.

Likuiditas adalah indikator kinerja bank yang ketiga. Dalam hal ini, Loan to Deposit Ratio (LDR) dapat digunakan untuk menilai likuiditas suatu bank dengan cara membagi jumlah kredit dengan jumlah dana (Almilia dan Herdiningtyas, 2005). Loan to Deposit Ratio (LDR) merupakan rasio yang menunjukkan kemampuan suatu bank dalam menyediakan dana kepada debiturnya dengan modal yang dimiliki oleh bank maupun dana yang dapat dikumpulkan dari masyarakat. Menurut Dendawijaya, Lukman (2003), Loan to Deposit Ratio (LDR) menyatakan seberapa jauh kemampuan bank dalam membayar kembali penarikan dana yang dilakukan deposan dengan mengandalkan kredit yang diberikan sebagai sumber likuiditasnya. Semakin tinggi Loan to Deposit Ratio (LDR) memberikan indikasi semakin rendahnya kemampuan likuiditas bank bersangkutan. Hal ini disebabkan karena jumlah dana yang diperlukan untuk membiayai kredit semakin besar.

Kemampuan mengelola resiko juga merupakan indikator penting dari kinerja suatu bank. Secara spesifik, menurut peraturan Bank Indonesia nomer 5 tahun 2003, risiko adalah potensi 
terjadinya peristiwa (event) yang dapat menimbulkan kerugian. Oleh karena situasi lingkungan eksternal dan internal perbankan mengalami perkembangan pesat peraturan Bank Indonesia tersebut, salah satu risiko usaha bank adalah risiko kredit, yang didefinisikan: risiko yang timbul sebagai akibat kegagalan counterparty memenuhi kewajiban. Credit Risk adalah risiko yang dihadapi bank karena menyalurkan dananya dalam bentuk pinjaman kepada masyarakat. Karena berbagai sebab, debitur mungkin saja menjadi tidak memenuhi kewajibannya kepada bank seperti pembayaran pokok pinjaman, pembayaran bunga dan lain-lain. Tidak terpenuhinya kewajiban nasabah kepada bank menyebabkan bank menderita kerugian dengan tidak diterimanya peneriman yang sebelumnya sudah diperkirakan.

Oleh karena itu perlu diantisipasi kemungkinan resiko yang mungkin timbul dalam rangka menjalankan usaha. Sehingga manajemen perlu meminimalisir risiko yang mungkin terjadi dalam pengelolaan faktor produksi, sumber dana, dan investment risk ratio, credit risk ratio, capital risk ratio, deposit risk ratio dan interest risk ratio. Pengukuran sangat berhubungan dengan pengukuran return, hal ini karena bank menghadapi risiko yang mungkin timbul disebabkan dalam rangka mendapatkan suatu return. Manajemen piutang merupakan hal yang sangat penting bagi perusahaan yang operasinya memberikan kredit, karena makin besar piutang akan semakin besar risikonya. Dengan demikian apabila suatu bank kondisi NPL tinggi maka akan memperbesar biaya baik biaya pencadangan aktiva produktif maupun biaya lainnya, sehingga berpotensi terhadap kerugian bank. NPL dihitung sebagai rasio dari jumlah kredit bermasalah terhadap total kredit (Kasmir, 2006).

Kemampuan manajemen perbankan merupakan indikator penting yang turut diperhitungkan dalam paper ini. Net Interest Margin merupakan rasio yang dapat menunjukkan kemampuan manajemen bank tersebut dalam mengelola aktiva produktifnya untuk menghasilkan pendapatan bunga bersih. Pendapatan bunga bersih diperoleh dari pendapatan bunga dikurangi beban bunga. Semakin besar rasio ini maka meningkatnya pendapatan bunga atas aktiva produktif yang dikelola bank sehingga kemungkinan bank dalam kondisi bermasalah semakin kecil (Almilia dan Herdiningtyas. 2005).

Menurut Rose P (2002) Net Interest Margin mengindikasikan seberapa baik kemampuan manajemen dan staf bank dalam memperoleh pendapatan (terutama dari kredit, investasi) dibandingkan dengan biaya (yang pada dasarnya berasal dari bunga deposito). Menurut Koch dan Scott (2000) Net Interest Margin penting untuk mengevaluasi kemampuan bank dalam mengelola risiko terhadap suku bunga. Saat suku bunga berubah, pendapatan bunga dan biaya bunga bank akan berubah. Sebagai contoh saat suku bunga naik, baik pendapatan bunga maupun biaya bunga akan naik karena beberapa aset dan kewajiban bank akan dihargai pada tingkat yang lebih tinggi.

Net Interest Margin (NIM) dihitung sebagai rasio dari pendapatan bunga bersih (net interest income) terhadap aktiva produktif. Pendapatan bunga bersih diperoleh dari selisih pendapatan bunga dengan beban bunga. Aktiva produktif merupakan penanaman dana 
bank baik dalam Rupiah maupun dalam bentuk valas dalam bentuk kredit, surat berharga, penempatan dana antar bank, penyertaan, termasuk komitmen dan kontinjensi pada transaksi rekening administrasi.

\subsection{Pengembangan Model Teoritis}

Model teoritis yang dikembangkan disajikan dalam bentuk diagram jalur sebagai berikut:

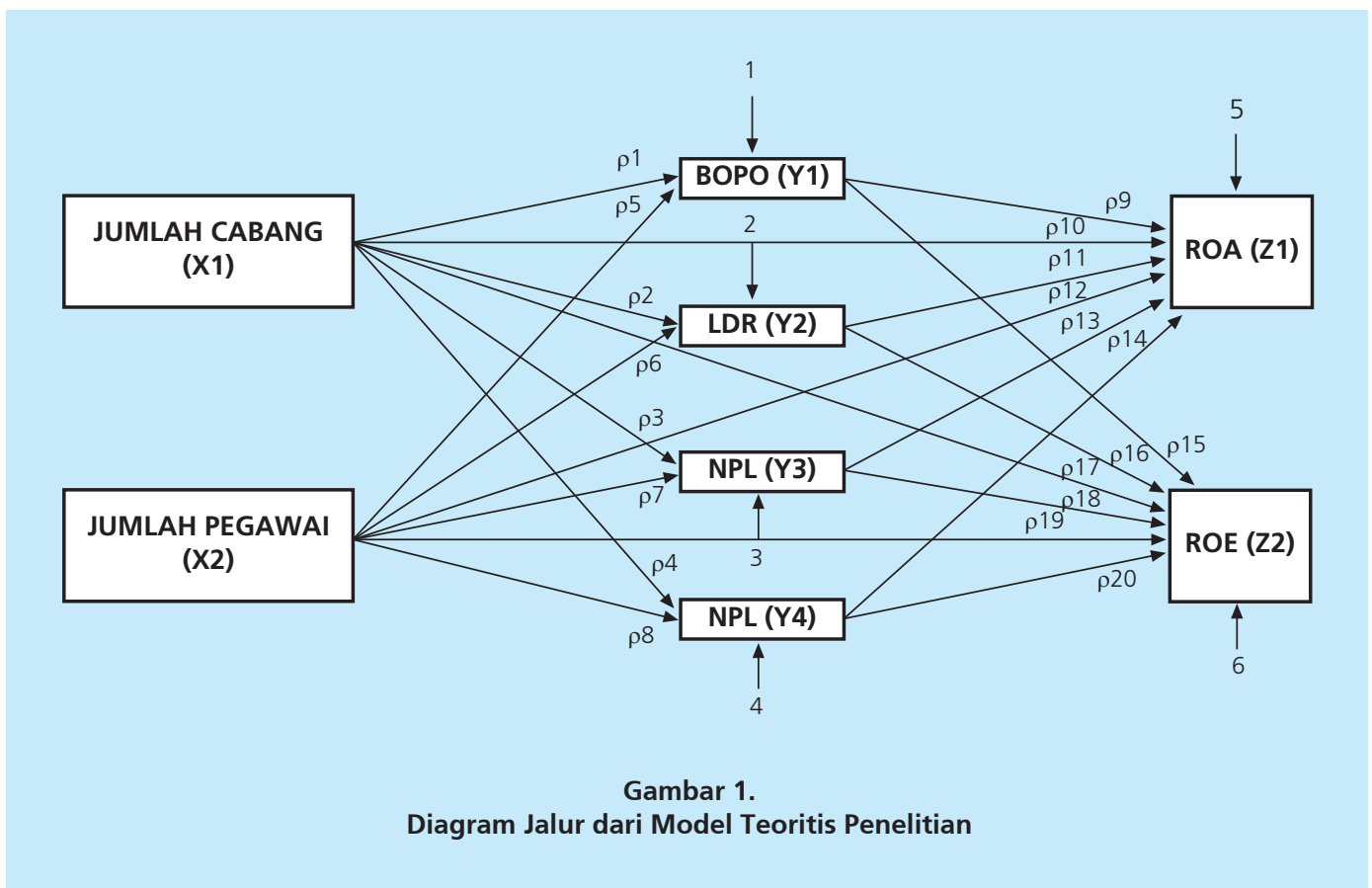

Kerangka konseptual di atas merupakan model struktural lengkap yang dapat diuraikan kedalam beberapa sub-struktur model di bawah ini. 
Sub Struktur 1: $(Y 1)=\rho_{1} X 1+\rho_{5} X 2+e_{1}$

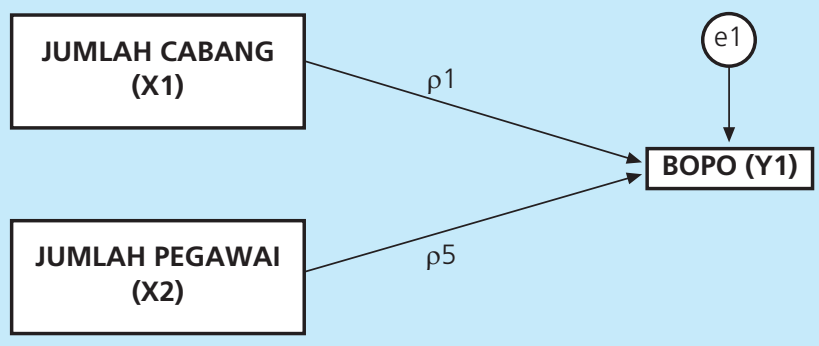

Gambar 2.

Diagram Model Substruktur 1

Sub Struktur $2(Y 2)=\rho_{2} X 1+\rho_{6} X 2+e_{2}$

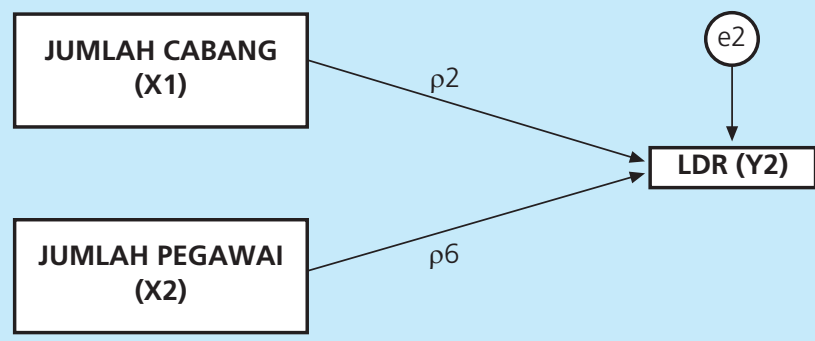

Gambar 3.

Diagram Model Substruktur 2

Sub Struktur $3(Y 3)=\rho_{3} X 1+\rho_{7} X 2+e_{3}$

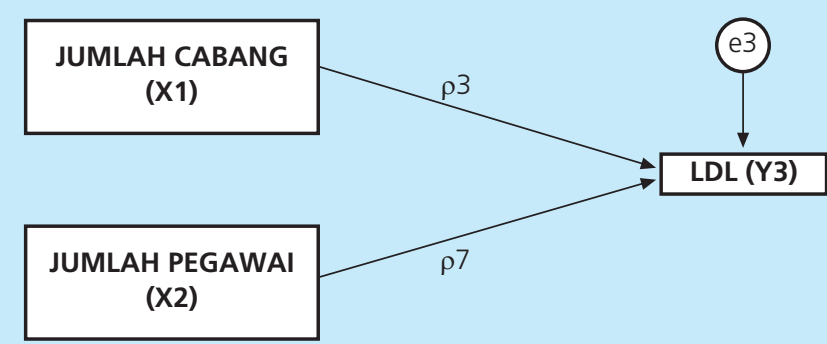

Gambar 4.

Diagram Model Substruktur 3 
Sub Struktur $4(Y 4)=\rho_{4} X 1+\rho_{8} X 2+e_{4}$

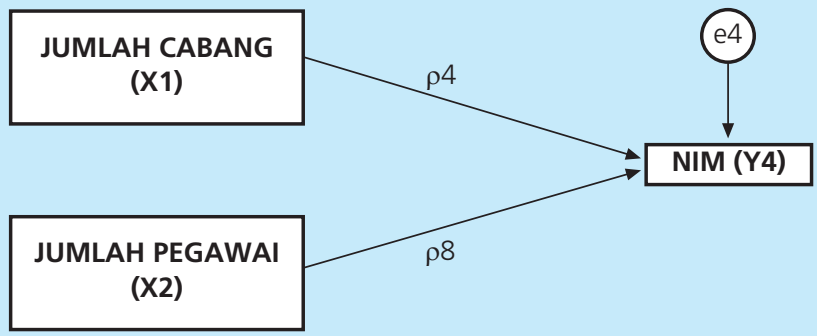

Gambar 5.

Diagram Model Substruktur 4

Sub Struktur $5(Z 1)=\rho_{9} X 1+\rho_{10} X 2+\rho_{11} Y 1+\rho_{12} Y 2+\rho_{13} Y 3+\rho_{14} Y 4+e_{5}$

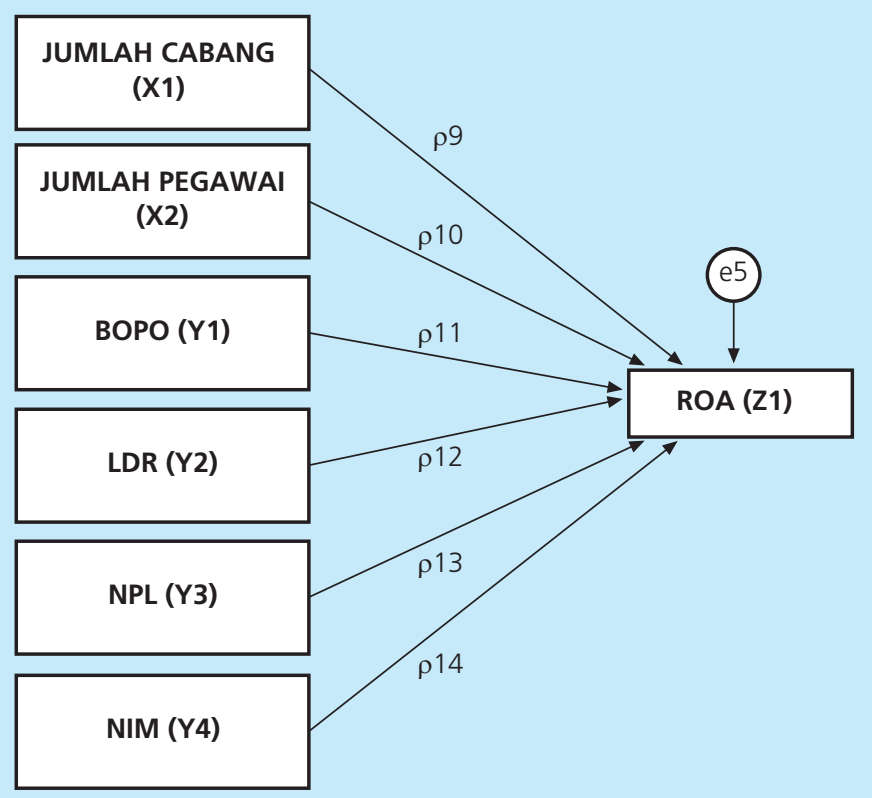

Gambar 6.

Diagram Model Substruktur 5 
Sub Struktur $6(Z 2)=\rho_{15} X 1+\rho_{16} X 2+\rho_{17} Y 1+\rho_{18} Y 2+\rho_{19} Y 3+\rho_{20} Y 4+e_{6}$

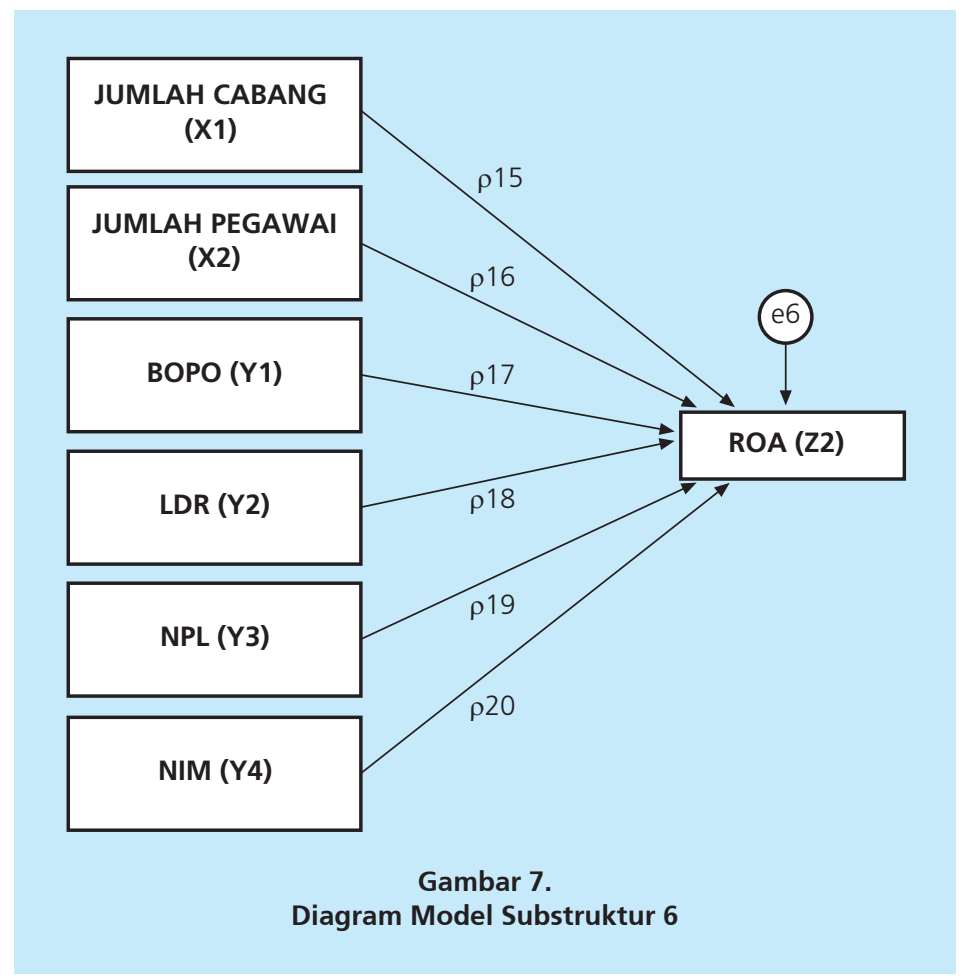

\section{METODOLOGI}

Model empiris yang digunakan dalam penelitian ini menggunakan analisis jalur (Path Analysis). Analisis jalur adalah suatu teknik pengembangan dari regresi linier ganda. Teknik ini digunakan untuk menguji besarnya sumbangan (kontribusi) yang ditunjukkan oleh koefisien jalur pada setiap diagram jalur dari hubungan kausal antar variabel X1 (penambahan jumlah cabang) dan X2 (penambahan jumlah pegawai) terhadap perubahan rasio Y1 (BOPO), Y2 (LDR), Y3 (NPL) dan Y4 (NIM) serta dampaknya terhadap perubahan rasio Z1 (ROA) dan Z2 (ROE). "Analisis jalur ialah suatu teknik untuk menganalisis hubungan sebab akibat yang tejadi pada regresi berganda jika variabel bebasnya memengaruhi variabel tergantung tidak hanya secara langsung tetapi juga secara tidak langsung". (Robert D. Retherford, 1993).

\subsection{Data}

Penelitian ini menggunakan populasi data seluruh perbankan di Indonesia tahun 2011 hingga 2012. Pada periode tersebut terdapat 120 bank di Indonesia. Penggunaan data ini dengan membandingkan data pada tahun 2012 dengan data pada tahun 2011 berupa delta 
$(\Delta) X 1, X 2, Y 1, Y 2, Y 3, Y 4, Z 1$ dan Z2. Hal ini dimaksudkan untuk memberi gambaran yang menyeluruh tentang pengaruh penambahan jumlah cabang dan jumlah pegawai pada seluruh bank umum di Indonesia baik bank persero, devisa, non devisa, bank pembangunan daerah (BPD), asing maupun campuran dan bank syariah terhadap kinerja masing-masing bank. Bank Perkreditan Rakyat (BPR) tidak termasuk dalam analisa mengingat skalanya masih kecil dan terbatasnya operasional dari BPR. Sumber data jumlah cabang, jumlah pegawai dan kinerja industri perbankan di Indonesia merupakan data sekunder dari Biro Riset Infobank sepanjang periode tahun 2011 - 2012.

Data perhitungan yang sudah ditabulasikan pada program microsoft excel merupakan data siap pakai untuk diexport ke program Amos versi 18.0 untuk tahapan analisis selanjutnya yaitu analisis statistik deskriptif dan pengaruh antara variabel dengan menggunakan Path Analysis. Variabel endogen (independen) pada penelitian ini adalah delta $(\Delta)$ jumlah cabang disebut jumlah cabang (X1) dan $\Delta$ jumlah pegawai disebut jumlah pegawai (X2). Sedangkan

\begin{tabular}{|c|c|c|c|c|c|}
\hline \multicolumn{6}{|c|}{$\begin{array}{c}\text { Tabel } 3 \\
\text { Deskriptif Statistik Variabel Penelitian }\end{array}$} \\
\hline Variabel & Periode & Min & Max & Mean & Std. Deviasi \\
\hline \multirow[t]{3}{*}{ Jumlah cabang } & 2011 & 0 & 2425 & 141,26 & 323,02 \\
\hline & 2012 & 0 & 2603 & 157,19 & 357,97 \\
\hline & Delta $(\Delta)$ & -62 & 273 & 15,93 & 43,02 \\
\hline \multirow[t]{3}{*}{ Jumlah pegawai } & 2011 & 0 & 62266 & 2531,41 & 7099,51 \\
\hline & 2012 & 0 & 65248 & 2759,02 & 7489,52 \\
\hline & Delta $(\Delta)$ & -907 & 2982 & 227,60 & 573,92 \\
\hline \multirow[t]{3}{*}{ BOPO } & 2011 & 35,44 & 114,63 & 79,79 & 14,80 \\
\hline & 2012 & 32,93 & 121,06 & 79,37 & 13,51 \\
\hline & Delta $(\Delta)$ & $-23,54$ & 33,83 & $-0,43$ & 7,21 \\
\hline \multirow[t]{3}{*}{ LDR } & 2011 & 42,57 & 559,97 & 91,66 & 55,92 \\
\hline & 2012 & 43,46 & 483,62 & 96,48 & 48,10 \\
\hline & Delta $(\Delta)$ & $-91,5$ & 75,81 & 4,82 & 19,74 \\
\hline \multirow[t]{3}{*}{ NPL } & 2011 & 0 & 7,87 & 1,88 & 1,55 \\
\hline & 2012 & 0 & 7,45 & 1,80 & 1,55 \\
\hline & Delta $(\Delta)$ & $-4,3$ & 5,36 & $-0,08$ & 1,35 \\
\hline \multirow[t]{3}{*}{ NIM } & 2011 & 0,81 & 15,10 & 6,03 & 2,55 \\
\hline & 2012 & 0,78 & 18,33 & 5,79 & 2,48 \\
\hline & Delta $(\Delta)$ & $-6,21$ & 8,18 & $-0,25$ & 1,50 \\
\hline \multirow[t]{3}{*}{ ROA } & 2011 & $-1,64$ & 7,44 & 2,31 & 1,48 \\
\hline & 2012 & $-1,4$ & 5,60 & 2,19 & 1,27 \\
\hline & Delta $(\Delta)$ & $-2,55$ & 1,84 & $-0,12$ & 0,78 \\
\hline \multirow[t]{3}{*}{ ROE } & 2011 & $-18,96$ & 41,73 & 14,24 & 10,93 \\
\hline & 2012 & $-3,38$ & 38,99 & 14,55 & 10,08 \\
\hline & Delta $(\Delta)$ & $-19,86$ & 19,22 & 0,31 & 5,18 \\
\hline
\end{tabular}


variabel eksogen (dependen) pada penelitian ini adalah $\Delta$ rasio BOPO disebut BOPO (Y1), $\Delta$ LDR disebut LDR (Y2), $\triangle$ NPL disebut NPL (Y3), $\triangle$ NIM disebut NIM (Y4), $\triangle$ ROA disebut ROA (Z1) dan $\triangle \mathrm{ROE}$ disebut ROE (Z2). Statistik deskriptif yang akan dibahas meliputi jumlah data, rata-rata, nilai maksimum, nilai minimum serta standar deviasi pada masing-masing variabel penelitian baik variabel endogen maupun eksogen seperti pada tabel berikut ini.

\subsection{Teknik Pengolahan Data}

Model empiris yang dikembangkan akan diolah dengan menggunakan metode Path Analysis atau Analisis Jalur. Pemilihan path analysis ini memungkinkan untuk menganalisis model empiris yang cukup kompleks, dan merupakan perluasan dari multiple regression. Model path analysis digunakan dalam menganalisis pola hubungan antar variabel dengan tujuan untuk mengetahui pengaruh langsung maupun tidak langsung seperangkat variabel bebas (eksogen) terhadap variabel terikat (endogen). Variabel eksogen dalam penelitian ini adalah $\Delta$ jumlah cabang $(X 1)$ dan $\Delta$ jumlah pegawai $(X 2)$. Sedangkan variabel endogen yaitu rasio-rasio $\Delta$ BOPO (Y1), $\Delta$ LDR (Y2), $\Delta$ NPL (Y3), $\Delta$ NIM (Y4), $\Delta$ ROA (Z1) dan $\Delta$ ROE (Z2). Path Analysis merupakan pengembangan dari multiple regression untuk itu syarat-syarat ketentuan dan pengujian regresi berganda juga berlaku untuk path analysis.

\subsubsection{Uji Asumsi Ketepatan Model}

Di dalam model analisis jalur, hubungan antara variabel adalah linear dan aditif. Uji linearitas menggunakan curve fit dan menerapkan prinsip parsimoni yaitu bilamana menggunakan curve fit dan menerapkan parsimoni, jika seluruh model signifikan atau tidak signifikan berarti dapat dikatakan model berbentuk linear.

1. Hanya model rekursif dapat dipertimbangkan, yaitu hanya sistem aliran kausal ke satu arah, sedangkan pada model yang mengandung kausal resiprokal tidak dapat dilakukan analisis jalur.

2. Pengamatan diukur tanpa kesalahan (instrumen pengukuran valid dan reliabel)

3. Model yang dianalisis dispesifikasikan (diidentifikasi dengan benar) berdasarkan teori-teori dan konsep yang relevan.

\subsubsection{Pemeriksaan Validitas}

Setelah melakukan uji asumsi terdapat indikator validitas model di dalam analisis jalur, yaitu koefisien determinan total keragaman data yang dapat diukur dengan rumus:

$$
x_{i}=\frac{(X i-\dddot{x i})}{S x i}
$$


Dimana variabel $X$ (capital) merupakan variabel asli yang belum distandarisasi (unstandarized) sedangkan variabel $\mathrm{x}$ (huruf kecil) adalah variabel $\mathrm{X}$ setelah distandarisasi. Jika variabel tersebut distandarisasi maka jumlahnya (sum) $\sum x_{i}=0$ dan varians serta deviasi standarnya $S_{x 1}^{2}=S_{x i}=1$. Dengan menjalankan regresi yang memakai variabel yang telah distandarisasi, maka akan didapat koefisien regresi yang telah distandarisasi. Pengujian tersebut sama dengan interpretasi koefisien determinasi $\left(R^{2}\right)$ pada analisis regresi dimana koefisien determinans $\left(R^{2}\right)$ menunjukkan sampai seberapa besar varians perubahan variabel independen yang terdiri dari jumlah cabang dan jumlah pegawai mampu menjelaskan varians perubahan variabel dependen. Koefisien determinan $\left(R^{2}\right)$ sama dengan 1 berarti variabel independen berpengaruh sempurna terhadap variabel dependen. Nilai $\left(R^{2}\right)$ besarnya antara nol $(0)$ dan satu (1) $\left(0 \leq R^{2} \leq 1\right)$, jika mendekati satu, maka kecocokan model dikatakan cukup untuk menjelaskan variabel dependen.

\subsubsection{Pendugaan Parameter Koefisien Path Analysis}

Pendugaan parameter lebih diimplementasikan dalam perhitungan koefisien path. Perhitungan koefisien pada gambar diagram path untuk anak panah satu arah $\rightarrow$ digunakan perhitungan regresi dengan data dibakukan (standardize data), secara parsiil pada masingmasing persamaan. Analisis jalur disamping ada pengaruh langsung juga terdapat pengaruh tidak langsung dan pengaruh total. Koefisien beta dinamakan koefisien jalur merupakan pengaruh langsung, sedangkan pengaruh tidak langsung dilakukan dengan mengalikan koefisien beta dari variabel yang dilalui. Pengaruh total dihitung dengan menjumlahkan pengaruh langsung dan pengaruh tidak langsung.

\section{HASIL DAN PEMBAHASAN}

\subsection{Pengaruh $X_{1}, X_{2}$ terhadap $Y_{1}$}

Hasil uji regresi standardize ditunjukkan tabel di bawah ini:

\begin{tabular}{|c|c|c|c|c|}
\hline \multicolumn{5}{|c|}{$\begin{array}{c}\text { Tabel } 4 \\
\text { Hasil Analisis Path } \mathrm{X}_{1}, \mathrm{X}_{2} \text { terhadap } \mathrm{Y}_{1}\end{array}$} \\
\hline Variabel & Beta & $\mathbf{t}$ & Sig $t$ & Keterangan \\
\hline$x_{1}$ & $-0,079$ & $-0,573$ & 0,567 & Tidak Signifikan \\
\hline $\mathrm{X}_{2}$ & $-0,028$ & $-0,205$ & 0,837 & Tidak Signifikan \\
\hline $\begin{array}{l}t_{\text {tabel }} \\
\text { R Square }\end{array}$ & $\begin{array}{l}=1,960 \\
=0,010\end{array}$ & & & \\
\hline
\end{tabular}




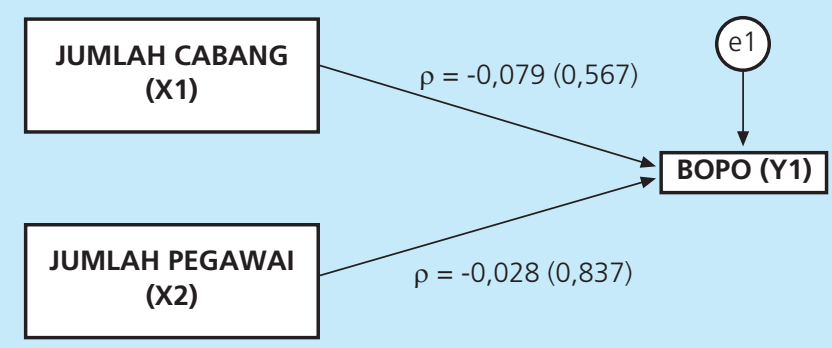

Gambar 8.

Diagram Hasil Analisis Model Substruktur 1

\subsection{Pengaruh $X_{1}, X_{2}$ terhadap $Y_{2}$}

Hasil uji regresi standardize ditunjukkan tabel di bawah ini:

\begin{tabular}{|c|c|c|c|c|}
\hline \multicolumn{5}{|c|}{$\begin{array}{c}\text { Tabel } 5 \\
\text { Hasil Analisis Path } X_{1}, X_{2} \text { terhadap } Y_{2}\end{array}$} \\
\hline Variabel & Beta & $\mathbf{t}$ & Sig $t$ & Keterangan \\
\hline$X_{1}$ & $-0,037$ & $-0,263$ & 0,793 & Tidak Signifikan \\
\hline $\mathrm{X}_{2}$ & 0,029 & 0,208 & 0,836 & Tidak Signifikan \\
\hline $\begin{array}{l}t_{\text {tabel }} \\
\text { R Square }\end{array}$ & \multicolumn{4}{|c|}{$=1,960$} \\
\hline
\end{tabular}

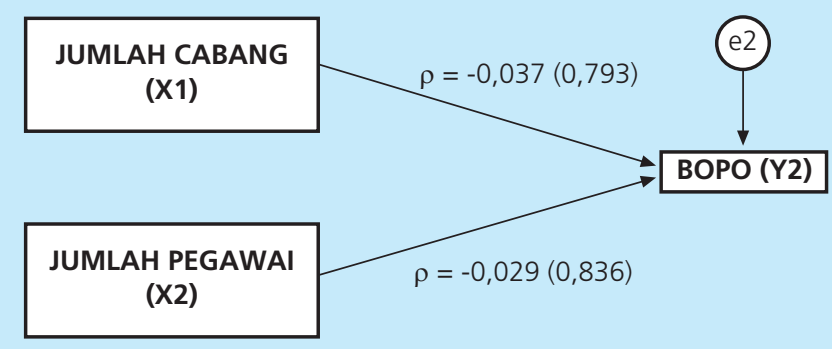

Gambar 9.

Diagram Hasil Analisis Model Substruktur 2 


\subsection{Pengaruh $X_{1}, X_{2}$ terhadap $Y_{3}$}

Hasil uji regresi standardize ditunjukkan tabel di bawah ini:

\begin{tabular}{|c|c|c|c|c|}
\hline \multicolumn{5}{|c|}{$\begin{array}{c}\text { Tabel } 6 \\
\text { Hasil Analisis Path } X_{1}, X_{2} \text { terhadap } Y_{3}\end{array}$} \\
\hline Variabel & Beta & $\mathbf{t}$ & Sig $t$ & Keterangan \\
\hline$X_{1}$ & $-0,039$ & $-0,282$ & 0,778 & Tidak Signifikan \\
\hline$x_{2}$ & 0,133 & 0,964 & 0,335 & Tidak Signifikan \\
\hline $\begin{array}{l}t_{\text {tabel }} \\
R \text { Square }\end{array}$ & & & & \\
\hline
\end{tabular}

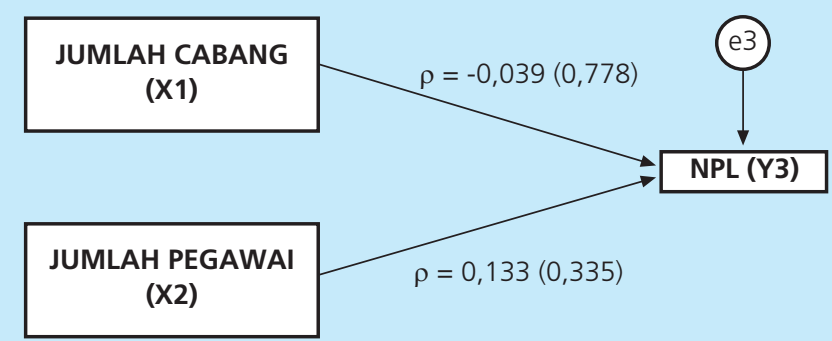

Gambar 10.

Diagram Hasil Analisis Model Substruktur 3

\subsection{Pengaruh $X_{1}, X_{2}$ terhadap $Y_{4}$}

Hasil uji regresi standardize ditunjukkan tabel di bawah ini:

\begin{tabular}{|c|c|c|c|c|}
\hline \multicolumn{5}{|c|}{$\begin{array}{c}\text { Tabel } 7 \\
\text { Hasil Analisis Path } \mathrm{X}_{1}, \mathrm{X}_{2} \text { terhadap } \mathrm{Y}_{4}\end{array}$} \\
\hline Variabel & Beta & $\mathbf{t}$ & Sig $\mathbf{t}$ & Keterangan \\
\hline $\mathrm{X}_{1}$ & 0,047 & 0,336 & 0,737 & Tidak Signifikan \\
\hline$x_{2}$ & 0,022 & 0,158 & 0,874 & Tidak Signifikan \\
\hline $\begin{array}{l}t_{\text {tabel }} \\
R \text { Square }\end{array}$ & & & & \\
\hline
\end{tabular}




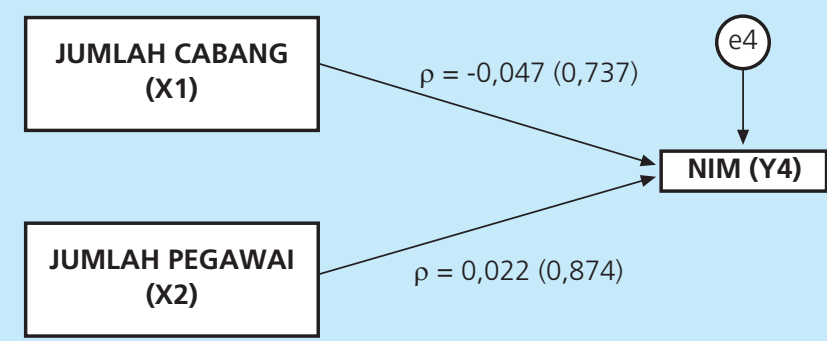

Gambar 11.

Diagram Hasil Analisis Model Substruktur 4

\subsection{Pengaruh $X_{1}, X_{2}, Y_{1}, Y_{2}, Y_{3}$ dan $Y_{4}$ terhadap $Z 1$}

Hasil uji regresi standardize ditunjukkan tabel di bawah ini:

\begin{tabular}{|c|c|c|c|c|}
\hline \multicolumn{5}{|c|}{$\begin{array}{c}\text { Tabel } 8 \\
\text { Hasil Analisis Path } X_{1}, X_{2}, Y_{1}, Y_{2}, Y_{3} \text { dan } Y_{4} \text { terhadap } Z_{1}\end{array}$} \\
\hline Variabel & Beta & $\mathbf{t}$ & Sig $t$ & Keterangan \\
\hline$X_{1}$ & $-0,104$ & $-1,207$ & 0,228 & Tidak Signifikan \\
\hline$x_{2}$ & 0,115 & 1,337 & 0,181 & Tidak Signifikan \\
\hline $\mathrm{Y}_{1}$ & $-0,729$ & $-12,344$ & 0,000 & Signifikan \\
\hline $\mathrm{Y}_{2}$ & 0,076 & 1,296 & 0,195 & Tidak Signifikan \\
\hline$Y_{3}$ & $-0,097$ & $-1,643$ & 0,100 & Tidak Signifikan \\
\hline $\mathrm{Y}_{4}$ & 0,262 & 4,460 & 0,000 & Signifikan \\
\hline $\begin{array}{l}t_{\text {tabel }} \\
R \text { Square }\end{array}$ & \multicolumn{4}{|c|}{$\begin{array}{l}=1,989 \\
=0,621\end{array}$} \\
\hline
\end{tabular}




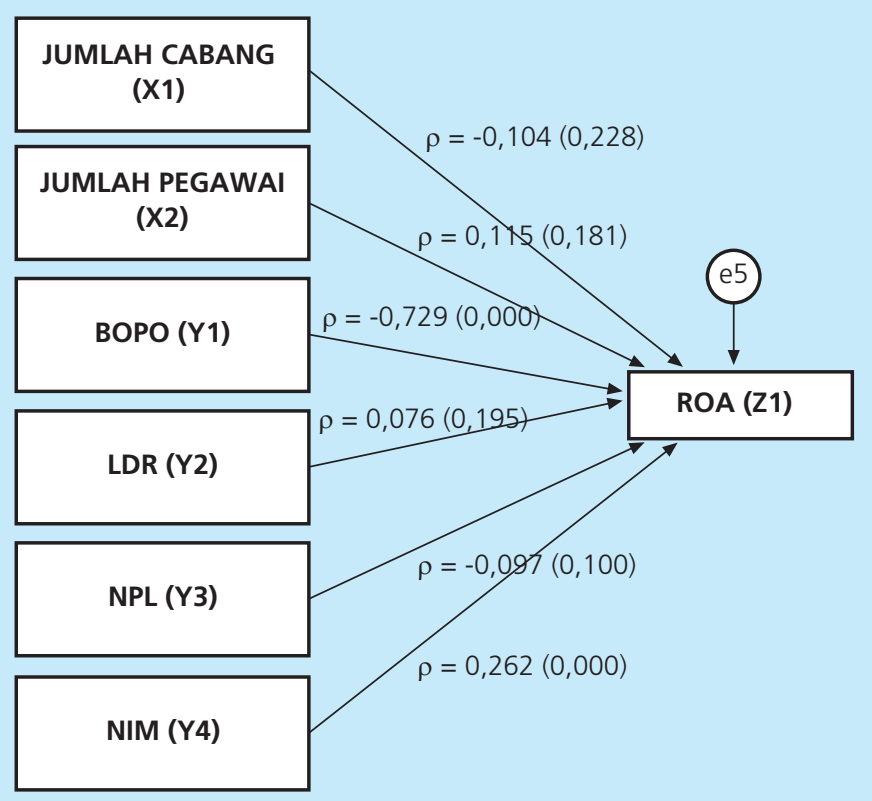

Gambar 12.

Diagram Hasil Analisis Model Substruktur 5

3.6. Pengaruh $X_{1}, X_{2}, Y_{1}, Y_{2}, Y_{3}$ dan $Y_{4}$ terhadap $Z 2$

Hasil uji regresi standardize ditunjukkan tabel di bawah ini:

\begin{tabular}{|c|c|c|c|c|}
\hline \multicolumn{5}{|c|}{$\begin{array}{c}\text { Tabel } 9 \\
\text { Hasil Analisis Path } X_{1}, X_{2}, Y_{1}, Y_{2}, Y_{3} \text { dan } Y_{4} \text { terhadap } Z_{2}\end{array}$} \\
\hline Variabel & Beta & $\mathbf{t}$ & Sig $t$ & Keterangan \\
\hline$X_{1}$ & $-0,113$ & $-1,056$ & 0,291 & Tidak Signifikan \\
\hline$x_{2}$ & 0,159 & 1,483 & 0,138 & Tidak Signifikan \\
\hline$Y_{1}$ & $-0,625$ & $-8,480$ & 0,000 & Signifikan \\
\hline $\mathrm{Y}_{2}$ & $-0,031$ & $-0,425$ & 0,671 & Tidak Signifikan \\
\hline $\mathrm{Y}_{3}$ & $-0,065$ & $-0,879$ & 0,379 & Tidak Signifikan \\
\hline$Y_{4}$ & $-0,010$ & $-0,142$ & 0,887 & Tidak Signifikan \\
\hline \multicolumn{5}{|c|}{$\begin{array}{l}=1,989 \\
=0,409\end{array}$} \\
\hline
\end{tabular}




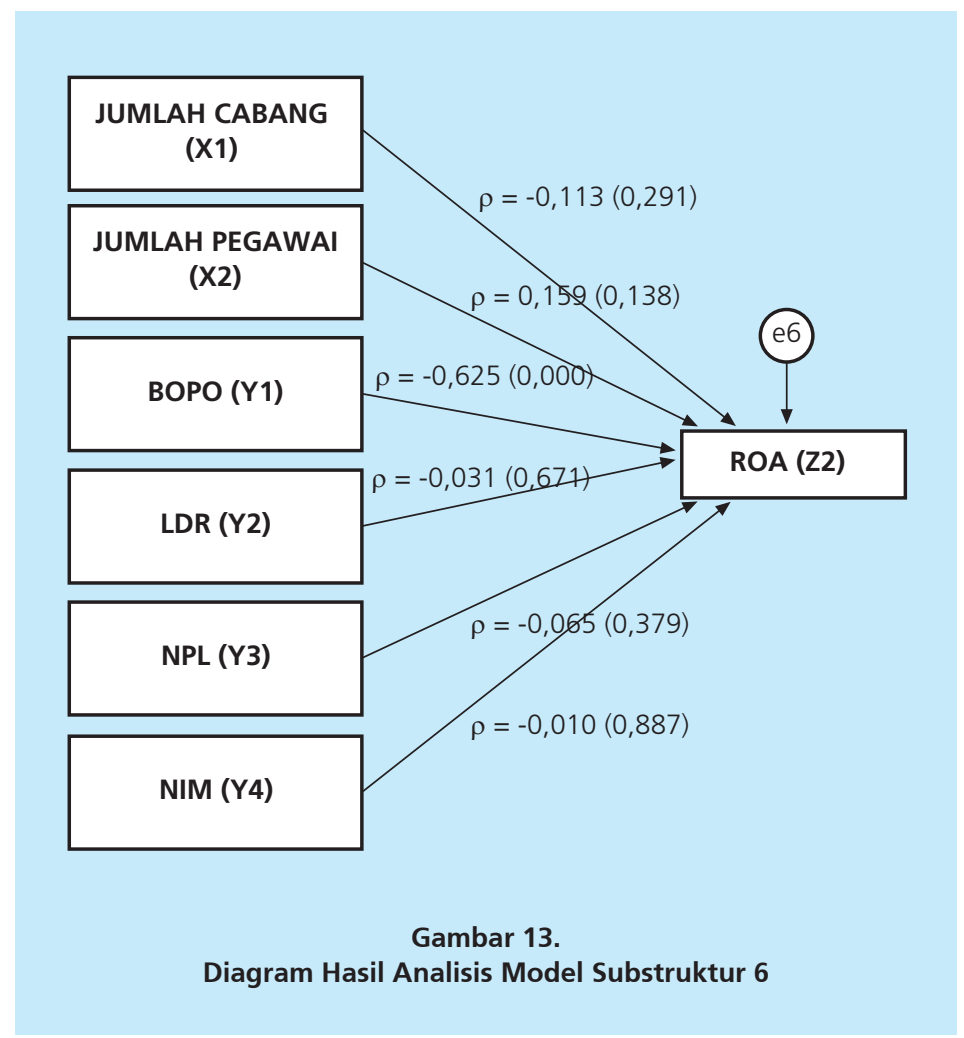

\subsection{Analisis Fit Model}

Berdasarkan uji kesesuaian model (fit model), diketahui bahwa model penelitian ini adalah fit karena memenuhi indeks pengujian berdasarkan rule of thumb yang disyaratkan. Artinya, model tersebut secara empirik dapat diujikan dan digunakan dalam penelitian ini. Hasil rangkuman pengujian tertera pada tabel berikut:

\begin{tabular}{l|r|r|l}
\multicolumn{5}{c}{ Tabel 10 } \\
\multicolumn{1}{c|}{ Hasil Uji Goodness of Fit Model } \\
Goodness of fit Index & Cut of value & \multicolumn{1}{c}{ Hasil } & \multicolumn{1}{c}{ Keterangan } \\
Chi-Square & $<$ Chi-Sq $5 \%$ & 37,443 & Model marjinal fit \\
\hline Probability & $>0,050$ & 0,000 & Model marjinal fit \\
\hline CMIN/DF & $<2,000$ & 5,349 & Model marjinal fit \\
\hline RMSEA & $<0,080$ & 0.199 & Model marjinal fit \\
\hline GFI & $>0,900$ & 0.929 & Model fit \\
\hline AGFI & $>0,900$ & 0.635 & Model marjinal fit \\
\hline
\end{tabular}


Pada Tabel di atas didapatkan nilai Chi-Square hitung sebesar 37,433 dan nilai probabilitas 0,000. Nilai Chi-Square hitung yang lebih besar dari nilai Chi-Square tabel $(37,433>14.067)$ atau nilai probabilitas yang lebih kecil dari alpha $5 \%(0,000<0,050)$ menyatakan bahwa hipotesis $\mathrm{H}_{0}$ ditolak yaitu matriks kovarians sampel berbeda dengan matriks kovarians estimasi atau dapat dikatakan bahwa model yang digunakan adalah cukup baik atau marginal fit.

Berdasarkan nilai RMSEA sebesar 0,199 yang lebih besar dari 0,080 dan nilai AGFI sebesar 0,635 yang lebih kecil dari nilai 0,900 maka dapat dikatakan bahwa model yang digunakan cukup baik atau marginal fit. Sedangkan berdasarkan nilai GFI sebesar 0,929 yang lebih besar dari nilai 0,900 menunjukkan bahwa model yang digunakan adalah model yang baik atau model fit.

\section{KESIMPULAN}

Berdasarkan hasil penelitian dan analisis data yang telah dilakukan, dapat diambil kesimpulan bahwa penambahan jumlah cabang dan jumlah pegawai industri perbankan di Indonesia tidak berpengaruh signifikan terhadap perubahan rasio BOPO, LDR, NPL, NIM, ROA dan ROE di tahun 2011-2012. Ternyata kinerja industri perbankan sepanjang periode tahun 2011-2012 tidak terpengaruh penambahan jumlah cabang dan jumlah pegawai, hal ini membuktikan bahwa ketidakefisienan industri perbankan sebagai salah satu indikator kinerja perbankan bukanlah hal utama yang disebabkan oleh penambahan jumlah cabang dan jumlah pegawai. Diperlukan penelitian lebih lanjut tentang biaya yang mendominasi ketidakefisienan perbankan di Indonesia.

Berdasarkan hasil kesimpulan diatas, maka kebijakan sebagian besar industri perbankan untuk membuka cabang baru guna melayani nasabah lebih baik lagi dan menambah jangkauan pelayanan ke seluruh wilayah Indonesia agar prosentase akses perbankan kepada masyarakat produktif meningkat masih tepat. Hal ini mengingat biaya investasinya tidak berpengaruh terhadap kinerja industri perbankan. Namun demikian perluasan akses perbankan (inklusif) bagi masyarakat produktif menggunakan teknologi informasi yang sudah berkembang sedemikian rupa seperti adanya branchless banking dengan biaya yang lebih efisien lagi dapat dilakukan. Penambahan jangkauan pelayanan ke seluruh wilayah Indonesia bagi industri perbankan di Indonesia sangat penting sejalan dengan akan akan diimplementasikannya Masyarakat Ekonomi Asean (MEA) di tahun 2015 dan MEA Keuangan tahun 2020. 


\section{DAFTAR PUSTAKA}

Amalia, Fitri dan Nasution, Mustafa Edwin. 2007. Perbandingan Profitabilitas Industri Perbankan Syariah dan Industri Perbankan Konvensional menggunakan Metode Struktur Kinerja dan Perilaku. Jurnal Ekonomi dan Pembangunan Indonesia. Vol VII, no.02, 2007.

Almilia, Luciana Spica dan Herdiningtyas, Winny. 2005. Analisis Rasio CAMEL terhadap Prediksi Kondisi Bermasalah pada Lembaga Perbankan Periode 2000-2002. Jurnal Akuntansi dan Keuangan, Vol, 7, No, 2, Nopember, hal,1-27, 2005.

Bank Indonesia. 2008. Statistik Perbankan Indonesia, Statistik PerbankanIndonesia, Volume 6, No 10, September 2008, Available online at http://www.bi.go.id/web/id.

Bikker, JA. 2002. Competition, Concentration, and Their Relationship: An Empiricalat The Banking Industry, Journal of Banking and Finance. 26(11), 2002.

Chaikal, Nuryakin dan Warjiyo, Perry. 2006. Perilaku Penawaran Kredit Bank di Indonesia: Kasus Pasar Oligopoli Periode Januari 2001 - Juli 2005. Buletin Ekonomi Moneter dan Perbankan, tahun 2006.

Derina, Ratna, and Willem A. Makaliwe. 2006. Perilaku Perbankan Indonesia: Beberapa Temuan Pattern dan Panel Data Analysis 1993-2005. Majalah USAHAWAN No.06 Th XXXV Juni 2006.

Dendawijaya, Lukman. 2003. Manajemen Perbankan. Penerbit Ghalia Indonesia, Jakarta.

Evanoff. D. D., and Fortier, D. L., 1988. Reevaluation of the Structure-Conduct-Performance Paradigm in Banking, Journal of Financial Services Research.1, 1988.

Gilbert, Alton R. B. 1984. Bank Market Structure and Competition: A Survey, Journal of Money, Credit, and Banking. November, 1984.

Gujarati, Damodar N. 2003. Basic Econometrics, 4th Edition. Mc Graw-Hill, New York.

Jatmiko, Pracoyo Budi. 2000. Paradigma Structure-Conduct-Performance versus Efficiency Hypothesis: Manakah yang Mencerminkan Industri Perbankan Indonesia?, Jurnal Ekonomi dan Bisnis Indonesia. Vol 15(3), 2000.

Koch, T., Scott. 2000. Bank Management. Harcourt Inc, Orlando, USA.

Kasmir. 2006. Manajemen Perbankan. Divisi Buku Perguruan Tinggi. Penerbit PT. Raja Grafindo Persada, Jakarta.

Kuncoro, M., Suhadjono. 2002. Manajemen Perbankan Teori dan Aplikasi Edisi Pertama. Penerbit BPFE, Yogyakarta.

Kirana J, Wihana dan Wanto, Nur.1998. Analisis Struktur dan Kinerja Industri Bank Swasta Nasional di Indonesia Tahun 1996. Jurnal Ekonomi dan Bisnis Indonesia. Vol 13 (1), 1998. 
Martin, Stephen. 1988. Industrial Economic - Economic Analysis and Public Policy. Second Edition, Macmillan Publishing Company. New York.

Mishkin, Frederick S \& Stanley G, 2000. Financial Market Institutions $4^{\text {th }}$ Ed.,AddisonWesley,USA.

Nachrowi D.N., Hardius Usman. 2006. Pendekatan Populer dan Praktis EKONOMETRIKA Untuk Analisis Ekonomi dan Keuangan. Penerbit LP-FEUI, Jakarta.

Nasser Katib, M. 2004. Market Structure and Performance in the Malaysian Banking Industry: a Robust Estimation. Universiti Utara Malaysia. Available online at http://papers.ssrn.com/ so/3/displayjel/cfn

Neuberger, Doris, 1997, Structure, Conduct, and Performance in Banking Markets. Working Paper no12. Universitat Rostock. Available online at http://econpapers.repec.org/RAS/ pne49.htm

Riyadi, Slamet. 2006. Banking Asets and Liability Management. Penerbit Lembaga Penerbit Fakultas Ekonomi Universitas Indonesia, Jakarta.

Rose, P. 2002. Commercial Bank Management. McGraw-Hill, New York, USA.

Sarita, Buyung. 2006. Pengaruh Tumpuan Pasaran, Penguasaan Pasaran, danAncaman Moral terhadap Prestasi Bank di Indonesia. (Unpublished Ph.DDissertation, Universiti Sains Malaysia. 2006). Available online at http://eprints.usm.my/9739/1

Sofyan, Sofriza. 2002. Pengaruh Struktur Pasar terhadap Kinerja Perbankan dilndonesia. Media Riset Bisnis dan Manajemen. Vol 2 (3) Desember 2002.

Yani K, Sri dan R, Lyla. 2006. Persaingan Perbankan di Indonesia. Buletin Ekonomi,4(2), 2006.

Setiawan, Ivan A dan Ritonga, Ferdiansyah. 2011. Analisis Jalur (Path Analysis) Dengan Menggunakan Program AMOS. Penerbit Suluh Media, Jakarta.

Sarwono, Jonathan. 2012. Path Analysis. Penerbit PT. Elex Media Komputindo, Jakarta.

Sipahutar, Mangasa A. 2007. Persoalan-persoalan Perbankan Indonesia. Penerbit Gorga Media, Jakarta.

Sugiyono. 2010. Metode Penelitian Bisnis.Penerbit Alfabeta, Bandung.

Taufik, Ariyanto. 2004. Profil Persaingan Usaha dalam Industri Perbankan Indonesia, Perbanas Finance and Banking Journal. Volume 6, No 2 Desember 2004.

W. Carlton, Dennis and M. Perloff, Jeffrey, . 2000. Modern Industrial Organization.Third Edition, Addison-Wesley, USA. 
106 Buletin Ekonomi Moneter dan Perbankan, Volume 18, Nomor 1, Juli 2015

Halaman ini sengaja dikosongkan 